
ВОЗРАСТА, ПРОЖИВАЮЩИХ НА ТЕРРИТОРИИ САРАТОВСКОЙ ОБЛАСТИ

Салина Т. Ю., Морозова Т. И.

ФГБОУ ВО «Саратовский государственный медицинский университет им. В. И. Разумовского» МЗ РФ, г. Саратов, РФ

\title{
GENETIC POLYMORPHISM AND DRUG RESISTANCE OF M. TUBERCULOSIS ISOLATED FROM TUBERCULOSIS PATIENTS OF VARIOUS AGE RESIDING IN SARATOV REGION
}

Salina T. Yu., Morozova T. I.

V. I. Razumovsky Saratov State Medical University, Saratov, Russia

Цель исследования: анализ частоты разных генотипов M. tuberculosis (МБТ) у больных туберкулезом разного возраста, постоянно проживающих на территории Саратовской области.

Материалы и методы. Проведен анализ медицинских документов 104 пациентов с туберкулезом легких и бактериовыделением, постоянных жителей Саратовской области, находившихся на стационарном лечении в Саратовском областном клиническом противотуберкулезном диспансере. Из них мужчин - 72 (69,2\%), женщин - 32 (30,8\%). В зависимости от возраста пациенты распределены на 3 группы. Группу 1 составили 23 пациента в возрасте от 18 до 30 лет. В группу 2 включено 62 пациента в возрасте от 31 года до 55 лет. Группу 3 составили 19 пациентов пожилого и старческого возраста (от 56 до 75 лет). Среди клинических форм туберкулеза у обследованной категории пациентов преобладал инфильтративный туберкулез легких - 63 (60,6\%), реже встречались диссеминированные - 20 (19,2\%), генерализованные формы туберкулеза - 9 (8,7\%). Другие формы туберкулеза (очаговый, фиброзно-кавернозный, туберкулемы и плеврит) встречались в единичных случаях - 12 (11,5\%). Из них с распадом в легочной ткани было 83 (79,8\%). Принадлежность МБТ к разным генетическим семействам определяли в образцах мокроты пациентов методом сполиготипирования и гибридизации на биологическом микрочипе с применением набора реагентов «Сполиго-биочип» (ООО «БИОЧИП-ИМБ», Москва). Результаты реакции учитывали с помощью аппаратно-программного комплекса «Чипдетектор-01» и специальной программы «ImaGeWare ${ }^{\circledR}$, позволяющей проводить сравнение сполиготипа с профилем сполиготипирования базы данных SpolDB4 (http:www.pasteur-guadeloupe.fr/tb/bd myco.html). Дополнительно проведено визуальное сравнение выявленных генотипов МБТ с базой данных SITVITWEB (/www.pasteur-guadeloupe. fr:8081/SITVIT_ONLINE). Лекарственную устойчивость (ЛУ) М̄БТ определяли молекулярно-генетическими методами (биочип с использованием тест-систем «ТВ-Биочип MDR» и «ТВ-Биочип-2» и аппаратно-програмного комплекса «Чипдетектор-01», Xpert ${ }^{\circledR}$ MTB/Rif с применением прибора GeneXpert $^{\circledR}$ («Cepheid», USA), методом абсолютных концентраций при посеве на твердые (Левенштейна - Йенсена и Финна 2) и жидкие питательные среды в системе Bactec MGIT 960.

Результаты. Установлено, что среди всей группы обследованных пациентов, больных туберкулезом, Саратовской области циркулирует 11 генетических семейств МБТ (Beijing, Beijing-like, Haarlem 1, 3, 4, Ural, LAM 9, 10, T1, 2, 4, 5, Manu, Microti, Rus 1, EA14 VNM, EA 15). Результаты распределения генотипов МБТ среди больных разного возраста представлены в таблице.

Как следует из таблицы, достоверные различия в распространении МБТ разных генотипов получены только в отношении Beijing и Haarlem. МБТ генотипа Beijing достоверно чаще встречались в группе лиц молодого возраста (группа 1) - 12 (52,2\%) по сравнению с лицами пожилого и старческого возраста (группа 3) - 4 (21,1\%), $p=0,0459$. МБТ генотипа Haarlem, наоборот, чаще встречались в группе 3 - $10(52,7 \%)$ против 5 (21,7\%) в группе 1 , $p=0,0437$.

У пациентов всех возрастных групп отмечался высокий уровень МЛУ (включая первичную и вторичную). В группе 1 - МЛУ МБТ встречалась в 8 (34,8\%) случаях, в группе 2 - в 15 (24,2\%), в группе 3 - в 11 (57,8\%) случаях. МБТ с МЛУ были представлены: в группе 1 в 4/8 (50\%) случаях семейством Beijing, в 2/8 (25\%) случаях - Haarlem и в $2 / 8(25 \%)$ случаях - семейством Т; в группе 2 в 6/15 (40\%) случаях - семейством Beijing, в $7 / 15$ (46,7\%) - Haarlem или Ural и в 2/15 (13,3\%) случаях - семейством Т; в группе 3 10/11 (90,9\%) случаев были представителями генотипов Haarlem или Ural. Моно- и полирезистентность существенно не различалась во всех группах обследованных.

\section{Выводы}

1. Среди больных впервые выявленным туберкулезом легких Саратовской области циркулирует 
Таблица. Частота встречаемости разных генетических семейств Mycobacterium tuberculosis у больных туберкулезом разного возраста

Table. Frequency of various genetic families of Mycobacterium tuberculosis in tuberculosis patients of various age

\begin{tabular}{|c|c|c|c|c|}
\hline Генотипы МБТ & $\begin{array}{c}\text { Группа } 1 \\
n=23 \text { (абс/\%) }\end{array}$ & $\begin{array}{c}\text { Группа } 2 \\
n=62 \text { (абс } / \%)\end{array}$ & $\begin{array}{c}\text { Группа 3 } \\
n=19(\text { абс/\%) }\end{array}$ & PХ⿱2 (между группами) \\
\hline Beijing+ Beijing-like & $12(52,2)$ & $23(37,1)$ & $4(21,1)$ & $\begin{array}{c}0,2152(1 \text { и } 2) \\
0,0459^{\star}(1 \text { и 3) } \\
0,1990(2 \text { и 3) }\end{array}$ \\
\hline Haarlem 1,3,4+Ural & $5(21,7)$ & $15(24,2)$ & $10(52,6)$ & $\begin{array}{l}0,8472 \text { (1 и 2) } \\
0,0437^{\star}(1 \text { и } 3) \\
0,0190^{\star}(2 \text { и } 3)\end{array}$ \\
\hline Другие (Rus 1, EAI, Canetti, Cas, Manu) & $2(8,7)$ & $12(19,4)$ & $2(10,5)$ & $\begin{array}{l}0,2340 \text { (1 и 2) } \\
0,8301 \text { (1 и 3) } \\
0,4823 \text { (2 и 3) }\end{array}$ \\
\hline
\end{tabular}

Примечание: * - различия статистически значимы $p<0,05$

11 генетических семейств МБТ (Beijing, Beijing-like, Haarlem 1, 3, 4, Ural, LAM 9, 10, T1, 2, 4,5, Manu, Microti, Rus 1, EA14 VNM, EA 15).

2. У лиц молодого возраста доминирующими были МБТ генотипа Beijing - 52,2\% против 21,1\% у лиц пожилого и старческого возраста.
3. У лиц пожилого и старческого возраста превалировали МБТ генотипа Haarlem - 52,6\% с самым высоким уровнем МЛУ - 57,8\%.

Салина Татьяна Юрьевна (Tatiana Yu. Salina) E-mail: SalinaTU@rambler.ru

\title{
ГЕНИТАЛЬНЫЙ ТУБЕРКУЛЕЗ И ВСПОМОГАТЕЛЬНЫЕ РЕПРОДУКТИВНЫЕ ТЕХНОЛОГИИ
}

Соцкий П. О., Соцкая О. Л., Сафарян М. Д.

Ереванский государственный медицинский университет им. Мх. Гераци, г. Ереван, Республика Армения

\section{GENITAL TUBERCULOSIS AND ASSISTED REPRODUCTIVE TECHNOLOGIES}

\author{
Sotskiy P. O., Sotskaya O. L., Safaryan M. D.
}

\section{Yerevan State Medical University named after Mkhitar Heratsi, Yerevan, Armenia}

В связи с развитием вспомогательных репродуктивных технологий (ВРТ) необходимость своевременной диагностики туберкулеза гениталий возросла. Милиарный туберкулез с множественной лекарственной устойчивостью (МЛУ-ТБ) - одно из потенциально смертельных осложнений беременности при туберкулезе после использования ВРТ.

Цель: диагностика МЛУ-ТБ у пациенток с бесплодием туберкулезного генеза.

Материалы и методы. Проведено проспективное обсервационное обследование женщин с подозрением на туберкулез. Использовали комплекс рентгенологических (компьютерная томография), эндоскопических (лапароскопия, гистероскопия) методов с биопсией, гистеросальпингографию. Методы верификации диагноза: патоморфологический, бактериоскопический, культуральный, молекуляр- но-генетический. Для выявления устойчивости микобактерий туберкулеза (МБТ) к противотуберкулезным препаратам применяли фенотипические и генотипические методы. Объект исследования на МБТ: асцитическая, перикардиальная, спинномозговая жидкость, биоптат эндометрия, операционный материал, менструальная кровь, отделяемое цервикального канала, моча, мокрота, жидкость бронхоальвеолярного лаважа.

Результаты. Наблюдали 141 женщину с генитальным туберкулезом с ВИЧ-негативным статусом. Диагноз верифицирован патоморфологическим методом у 72 женщин, у 54 - культуральным, у 18 - обоими методами. У 10/141 (7,1\%) обнаружен туберкулез с МЛУ МБТ (9) и ШЛУ МБТ (1). У 77 пациенток диагностировано бесплодие, в программах ВРТ участвовали 20 пациенток. Ми- 